\title{
Kekuatan Kolaborasi dalam Membangun Kampung Kota di Wilayah Kelurahan Klitren, Yogyakarta
}

\author{
Paulus Bawole \\ \#Program Studi Arsitektur, Universitas Kristen Duta Wacana \\ Jl. Dr. Wahidin Sudirohusodo No. 5-25, Yogyakarta \\ 1paulus@staff.ukdw.ac.id
}

\begin{abstract}
Abstrak-Merujuk pada target SDG 2030 yang dicanangkan PBB beberapa tahun lalu, banyak hal yang masih perlu menjadi target pembangunan di banyak negara berkembang. Sasaran yang erat kaitannya dengan perkembangan kota-kota di negara berkembang seperti Indonesia adalah pengembangan mengembangkan Kampung Kota di Kelurahan Klitren dilakukan secara kolaboratif berbasis masyarakat. Kolaborasi untuk membangun Kampung Kota dilakukan oleh berbagai institusi seperti dari Pemerintah Daerah, Pemerintah Pusat melalui konsultan, akademisi dan juga bersama-sama dengan masyarakat setempat. Proses yang dilakukan secara partisipatif ini dilakukan untuk mempertajam pemberdayaan masyarakat dan melakukan transfer of knowledge agar keberlanjutan pembangunan di Wilayah Kelurahan Klitren dapat dikembangkan secara mandiri oleh komunitas setempat. Artikel ini membagikan dan mendiskusikan pengalaman bekerja bersama masyarakat secara kolaboratif untuk meningkatkan kualitas Kampung Kota di wilayah Kelurahan Klitren, Yogyakarta yang diwujudkan dalam perencanaan dan perancangan fasilitas infrastruktur beserta lingkungan permukimannya.
\end{abstract}

Kata Kunci: Kolaborasi, Pembangunan, Kampung Kota, Partisipasi, Pemberdayaan .

Abstract-Referring to the target of SDG 2030 that was proclaimed by the United Nations several years ago, there are many things that still need to be development targets in many

\section{, Empowerment.}

\section{Pendahuluan}

Kampung kota meruapakan salah satu ciri khas bagian wilayah kota di Indonesia yang berkembang secara sporadic tanpa ada perencanaan. Pada umumnya pada bagian wilayah kampong kota ini tinggal masyarakat yang bisa digolongkan masyarakat berpenghasilan menengah ke bawah. [1] Karena berkembang secara spontan dan sporadic, maka kampung kota tidak mempunyai pola permukiman khusus atau sering kali dikatakan dengan pola permukiman organik. Pada permukiman kampung kota ada
Kampung Kota yang masih belum sepenuhnya berkembang. Salah satu sasaran pengembangan Kampung Kota di Yogyakarta adalah wilayah Kelurahan Klitren. Metode yang digunakan untuk

developing countries. The targets that are closely related to the development of cities in developing countries such as Indonesia are the development of Urban Kampong which is still not fully developed. One of the targets for the development of Urban Kampong in Yogyakarta is the areas of Klitren sub-district. The method used to develop Urban Kampong in Klitren Subdistrict is carried out in a community-based collaborative manner. Collaboration to build Urban Kampong is carried out by various institutions such as from the Regional Government, the Central Government through consultants, academics and also together with the local community. This participatory process is carried out to sharpen community empowerment and transfer of knowledge so that sustainable development in the Klitren Urban Kampong can be developed independently by the local community. This article shares and discusses the experiences of working collaboratively with the community to improve the quality of Urban Kampung in the area of Klitren Sub-district, Yogyakarta which is realized in the planning and design of infrastructure facilties as well as their surrounding settlement.

Keywords: Collaboration, Development, Kampung Kota, Participation

banyak program perbaikan kampung yang dilakukan pemerintah yang dikaitkan dengan target Sustainable Development Goals 2020 khususnya pada target No.1 (End Poverty for all - Mengakhiri kemiskinan dalam segala bentuk); 6 (Clean Water and Sanitation - Air Bersih dan Sanitasi); dan 11 (Sustainable Cities and Communities Kota dan Komunitas yang Berkelanjutan). [2] Salah satu kampong kota yang dikembangkan untuk meningkatkan kwalitas lingkunan permukiman dan masyarakatnya adalah kampung - kampung di wilayah Kelurahan Klitren.

Secara administrasi Kelurahan Klitren berada di wilayah Kemantren Gondokusuman, Kota Yogyakarta. [3] Lokasi 
Kelurahan Klitren berada pada poros pusat perkotaan yang kedua setelah kawasan Malioboro yang membujur dari Barat ke Timur menghubungkan kota Yogyakarta ke Klaten dan Solo. Kawasan Pusat Bisnis (Central Business District $=\mathrm{CBD}$ ) yang membelah Kelurahan Klitren menjadi dua membuat kawasan ini menjadi sangat pernting untuk direncanakan perkembangannya. [3]

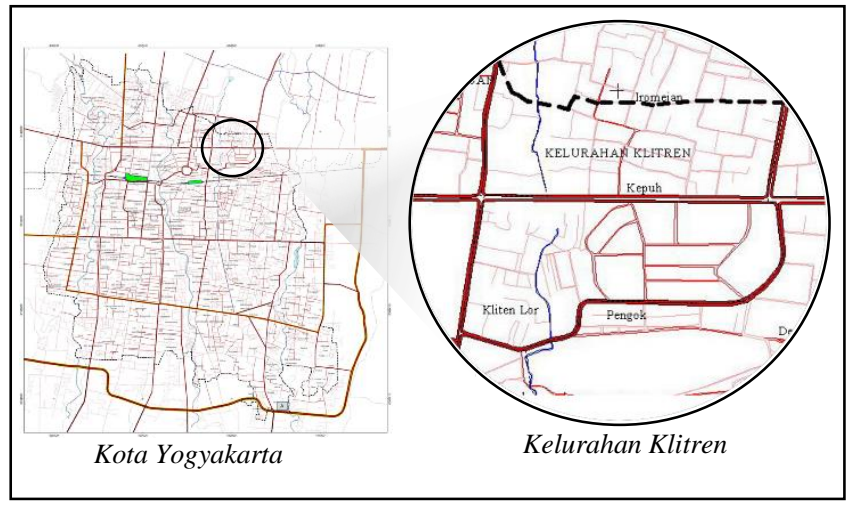

Gambar 1. Posisi Kelurahan Klitern di Wilayah Kota Yogyakarta Sumber: Dokumentasi PLPBK Kota Yogyakarta

Dengan posisi yang strategis ini Kelurahan Klitren harus direncakan pengembangannya dalam periode beberapa tahun ke depan. Proses pembuatan rencana pengembangan Kelurahan Klitren menjadi menarik ketika beberapa institusi secara bersama-sama dengan masyarakat berkolaborasi untuk membuat perencanaan pengembangan wilayah Kelurahan Klitren. Kolaborasi membuat rencana pengembangan wilayah Kelurahan Klirten ini dilakukan oleh Pemerinath Daearah Kotamadya Yogyakarta dalam hal ini Dinas PU PKP, Progam Kota Tanpa Kumuh (Kotaku) Yogyakarta, Laboratorium Lingkungan Kota dan Permukiman (LLKP) - Fakultas Arsitektur dan Desain , Universitas Kriten Duta Wacana. Proses kolaborasi pembuatan rencana pengembangan wilayah Kelurahan Klitren akan dijabarkan dalam artikel pengabdian kepada masyarakat ini.

\section{Gambaran Umum Wilayah Kelurahan Klitren}

Dengan Luas total 0,68 KM2 kelurahan Klitren mempunyai $16 \mathrm{RW}$ yang terbagi dalam $63 \mathrm{RT}$. Sedangkan Jarak dari pemerintah pusat (Orbitrasi) Kelurahan Klitren adalah sebagai berikut: [4]

$>$ Jarak dari Pusat Pemerintahan Kecamatan : 0,8 Km

$>$ Jarak dari Pusat Pemerintahan Kota $\quad: 1,5 \mathrm{Km}$

$>$ Jarak dari Kota / Ibu Kota Kabupaten : $1,5 \mathrm{Km}$

$>$ Jarak dari Ibukota Propinsi $\quad: 3 \mathrm{Km}$
Posisi Wilayah Kelurahan Klitren cukup strategis karena relative dekat dengan pusat pemerintahan Kecamatan, Kota dan Propinsi. Selain itu poros kawasan CBD membuat jalan Solo membuat kawasan ini menjadi tujuan para pencari kerja yang akhirnya tinggal di kampung kota dibelakang kawasan perdagangan jalan Solo. Dengan demikian wilayah Kelurahan Klitren yang dibelah holeh Jalan Solo berkembangan secara spontan dengan kepadatan yang relative tinggi.

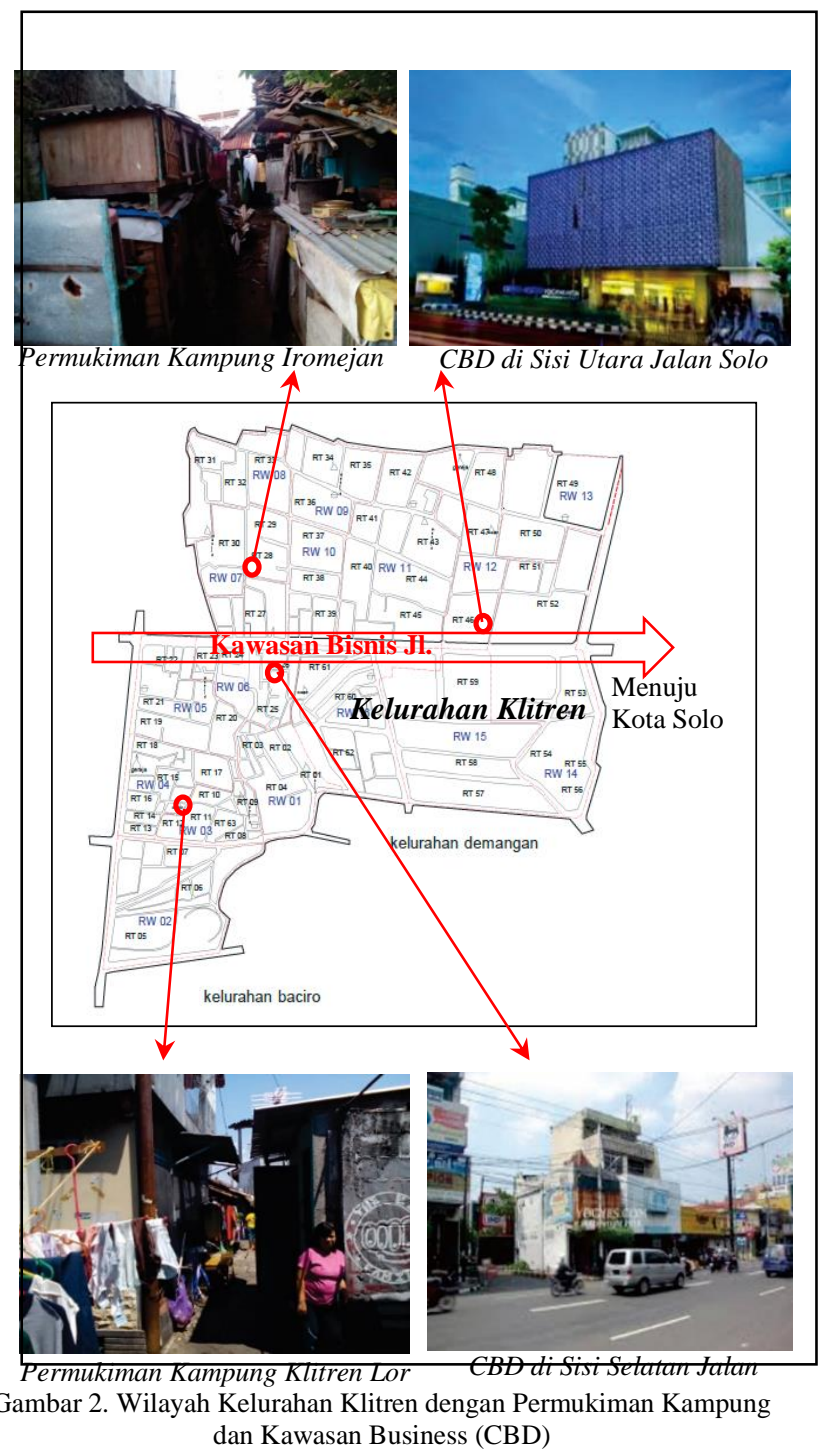

Kelurahan Klitren terdiri dari 16 RW dan 63 RT serta terdiri atas 3 ((Tiga) kampung yaitu Kampung Kepuh Balapan, Klitren Lor, dan Iromejan. Jumlah penduduk dikelurahan Klitren sebanyak 9.690 jiwa yang terdiri dari penduduk laki-laki 4.742 jiwa dan perempuan 4.948 jiwa [4] 
TABEL I

Pertumbuhan PENduduk Kelurahan KLITREn TAhun 2017-2019

\begin{tabular}{|c|r|r|r|r|}
\hline Tahun & $\begin{array}{c}\text { Penduduk } \\
\text { Laki-Laki }\end{array}$ & $\begin{array}{c}\text { Penduduk } \\
\text { Perempuan }\end{array}$ & $\begin{array}{c}\text { Jumlah } \\
\text { Penduduk }\end{array}$ & Pertumbuhan \\
\hline 2017 & 4.596 & 4.844 & $\mathbf{9 . 4 4 0}$ & \\
\hline 2018 & 4.660 & 4.907 & $\mathbf{9 . 5 6 7}$ & 127 \\
\hline 2019 & 4.719 & 4.950 & $\mathbf{9 . 6 6 9}$ & 102 \\
\hline 2020 & 4.742 & 4.948 & $\mathbf{9 . 6 9 0}$ & 21 \\
\hline
\end{tabular}

Sumber: Dokumentasi PLPBK Kota Yogyakarta

\section{A. Kondisi Ekonomi, Sosial, dan Budaya}

Kondisi sosial dan ekonomi di Kelurahan Klitren kebanyakan mengandalkan pada sektor-sektor seperti sektor jasa, permukiman, perdagangan, pariwisata dan buruh. Dibawah ini dijelaskan secara singkat peranan masing-maasing sector.

\section{Sektor Jasa}

Pada sektor jasa penduduk Kelurahan Klitren kebanyakan mengandalkan jasa pencucian baju (laundry), persewaan motor, bengkel motor, jasa tukang jahit, dan salon.

\section{Sektor Perdagangan}

Pada Sektor perdagangan penduduk Kelurahan Klitren kebanyakan adalah perdagangan skala rumah tangga dengan membuka toko, warung, dan rumah makan di depan rumah.

\section{Sektor Permukiman}

Pada Sektor Permukiman penduduk Kelurahan Klitren banyak yang membuka kos-kosan. Hal ini didukung dengan letak kawasan Kelurah Klitren yang berada pada kawasan perdagangan, jasa dan kawasan pendidikan sehingga banyak orang membutuhkan kamar kost.

\section{Sektor Pariwisata}

Pada sektor Pariwisata di Kelurahan Klitren didukung oleh adanya Embung Langensari. Dengan adanya Embung ini masyarakat dapat mengembangkannya sebagai tempat wisata.

\section{Sektor Buruh}

Pada Sektor buruh, didukung oleh adanya Hotel, Bioskop, Pertokoan hingga Supermarket yang banyak terdapat di Kelurahan Klitren yang dapat menyerap cukup banyak tenaga kerja dari warga Kelurahan klitren sendiri.

\section{B. Kondisi Fisik Dasar}

Secara Geografis kelurahan Klitren terletak diketinggian $\pm 102 \mathrm{~m}- \pm 130 \mathrm{~m}$ diatas permukaan laut (dpa). Memiliki kemiringan lahan yang datar (antara 0-2. Sebagian besar tanahnya berupa tanah regosol atau vulkanis muda. Bersumber dari data Rencana Detail Tata Ruang kota Yogyakarta tahun 2012, bahwa curah hujan rata-rata 2.012 $\mathrm{mm} /$ thn dengan 119 hari hujan, suhu rata-rata $27,2^{\circ} \mathrm{C}$ dan kelembaban rata-rata $24,7 \%$.

\section{Pemanfaatan Lahan di Kelurahan Klitren}

Pemanfaatan lahan di wilayah Kelurahan Klitren dapat diidentifikasikan sesuai denga peruntukan pada tiap blok sebagai berikut:

\section{Perumahan}

Fasilitas perumahaan didasarkan pada intensitas kepadatan penduduk setiap kawasan.

\section{Perdagangan dan Jasa}

Fasilitas perdagangan dialokasikan pada koridor jalan-jalan arteri dan kolektor, dengan penekanan intensitas pada kawasan subpusat pelayanan, yang diintegrasikan dengan ruang terbuka.

\section{Sarana Umum}

Fasilitas sarana umum didasarkan pada cakupan skala pelayanan pada setiap kawasan dalam upaya memenuhi kebuutuhan penduduk dan skala pengembangan fasilitas yang meliputi sarana pendidikan, kesehatan, peribadatan, sarana social, rekreasi, pelayanan umum, pemberlanjaan/niaga dan transportasi.

\section{Industri dan Perdagangan}

Fasilitas industri dan perdagangan dialokasikan pada wilayah dengan tingkat permukiman rendah dan diarahkan pada rencana trasportasi yang berhubungan dengan bahanbaku dan pemasaran hasil produksi yang merupakan bagian dari rencana jaringan trasportasi.

\section{Ruang Terbuka Hijau}

Fasilitas RTH dialokasikan pada tempat-tempat yang dapat dijadikan berbagai jenis kegiatan dengan mengoptimalkan fungsi ruang terbuka sebagai aktivitas sosial dan budaya. RTH juga sebagai pembatas yang menegaskan peralihan antara suatu fungsi dengan fungsi lain seperti pada sempadan sungai yang memisahkan kawasan permukiman dengan sungai.

\section{Khusus}

Fasilitas khusus meyediakan ruang bagi kegiatan yang tertentu yang sifatnya mempunyai kekhususan diluar ketetapan pada blok lain. Fasilitas ini meliputi kawasan militer yang memerlukan penanganan operasional yang khusus dan kawasan yang ditetapkan sebagai kawasan lindung atau kawasan heritage.

Kebutuhan akan lahan permukiman tentu membuat berkurangnya lahan untuk peruntukan yang lain seperti 
Sarana Umum serta Ruang Terbuka Publik. Hal ini terkait dengan kepadatan penduduk di Klitren sebesar 75 Jiwa per Ha dengan jumlah penduduk miskin yang mencapai 1473 Jiwa.

\section{Kondisi Fisik Bangunan di Kelurahan Klitren}

Berdasarkan data baseline, 267 unit bangunan dari total bangunan 1129 unit yang tersebar di 16 RW Kelurahan Klitren masih belum teratur. Data menunjukkan sebanyak 175 dari total 1129 kepala rumah tangga (KRT) sekelurahan Klitren masih memiliki area hunian yang kurang dari $7,2 \mathrm{~m}^{2}$. Berdasarkan wawancara responden, hal ini disebabkan karena sebuah bangunan sempit yang dihuni oleh lebih dari satu Kepala Keluarga (KK). Sebanyak 165 unit bangunan rumah tangga dari total bangunan 1129 unit sekelurahan Klitren masih memiliki masalah.

\section{E. Fasilitas Infrastruktur Jalan}

Keadaan infrastruktur jalan di kelurahan Klitren, kondisinya sudah cukup baik meskipun beberapa titik tertentu masih terdapat perbaikan. Berbeda dengan jalan lingkungan yang dibangun berdasarkan adanya lahan yang tersedia bukan karena kemanfaatan. Berdasarkan data baseline, jalan lingkungan yang ada di Kelurahan Klitren sepanjang $21531 \mathrm{~m} .4737 \mathrm{~m}$ jalan lingkungan masih memiliki lebar $\leq 1,5 \mathrm{~m} 2$. Lebar jalan yang sempit merupakan indikasi bahwa kemampuan jalan lingkungan untuk mendukung lintas transportasi ataupun lintas warga masih kurang memenuhi syarat.

\section{F. Fasilitas Infrastruktur Teknis}

Fasilitas infrastruktur teknis di wilayah Kelurahan Klitren menurut observasi lapangan sudah cukup memadai, walaupun masih banyak juga yang dalam kondisi memprihatinkan. Beberapa fasilitas infrastruktur teknis akan dijelaskan secara singkat dibawah ini.

\section{Jaringan Drainage}

Drainase yang tersedia baik adalah drainase dengan kecukupan kualitas serta kuantitas yang memadai. Hal ini bisa kita lihat dari ada tidaknya genangan yang terjadi di Klitren. Drainase ini selain diperlukan perhatiannya terhadap elevasi juga perlu diperhatikan daya dukung terhadap air yang dialirkan drainase tersebut. Selain hal tersebut perlu pula adanya pembedaan antara drainase dengan saluran limbah. Seringkali di perkotaan hal ini di campur akibatnya tentu saja drainase tidak mendapatkan daya dukung yang memadai. Selain Akan menimbulkan genangan limbah yang mencemari dan tidak sehat.

\section{Jaringan Persampahan}

Persampahan di Klitren kurang terkelola dengan baik, meskipun telah dilakukan pengambilan sampah secara rutin tetapi karena pola hidup bebas sampah belum menjadi gaya hidup maka pengelolaan sampah masih belum optimal. Pola 3R melalui Bank sampah juga telah dilakukan dikelurahan Klitren dengan nama Bank Sampah Anugerah 11 beralamat di RT 43 RW.11 Kelurahan Klitren Kec. Gondokusuman. Bank sampah ini berdiri pada November 2013,bank sampah ini mencakup RW 11 yang terdiri dari 3 RT(RT 41,42,43). Pengumpulan sampah dilakukan 1 minggu sekali pada hari jumat, bank sampah ini baru melakukan pemilahan dan penjualan sampah, belum sampai ke pengolahan sampah, karena warga sekitar cenderung sibuk dengan pekerjaannya, bantuan dari BLH berupa buku tabungan dan tas pilah sampah. Pendirian bank sampah ini adalah bagian dari mendukung program pemerintah khususnya pengelolaan sampah, dulu sampah dianggap tidak berguna tapi kini sampah dapat dimanfaatkan sekaligus dapat menambah pendapatan.

\section{Jaringan Air Minum}

Pertambahan penduduk, bertambahnya sektor perdagangan, perhotelan, kos serta pola boros air merupakan penyebab tingkat kebutuhan air yang semakin tinggi dari tahun ke tahun. Mudahnya perijinan pengambilan sumber air dalam menyebabkan penggunaan air yang tidak terkontrol. Jaringan PDAM yang di buat tetap belum memenuhi semua kebutuhan warga. Sehingga warga memanfaatkan dua sumber sekaligus yaitu sumur serta PDAM. Hal ini ditambah masih kurangnya daerah resapan air. Pemanfaatan Ruang Terbuka Publik (RTP) sebagai sumber resapan juga perlu dioptimalkan.

\section{Jaringan Limbah}

Sesuai dengan laju pertambahan penduduk baik dari dalam kelurahan sendiri maupun dari luar kelurahan misalnya dari kos serta bertambahnya wisma serta homestay, semakin menambah resiko adanya pencemaran limbah. Pola perilaku masyarakat juga bisa membuat Limbah ini semakin memburuk. Ketersediaan lahan juga menjadi faktor krusial didalam pengolahan limbah baik domestik maupun dari perdagangan atau industri.

Penanganan limbah domestik di Kota Yogyakarta termasuk di wilayah Kelurahan Klitren pada umumnya dilakukan dengan 3 sistem,

- Sistem terpusat yang dialirkan menuju IPAL Sewon dengan pelayanan $25 \%$ penduduk Kota Yogyakarta

- Sistem komunal dan setempat; bagi penduduk yang wilayahnya tidak terjangkau oleh jaringan air limbah Pemerintah Kota Yogyakarta, mereka membangun Instalasi Septic Tank Komunal untuk mengolah air limbah domestik maksimal untuk 5 orang KK.

- Pengolahan Air Limbah (IPAL) Komunal untuk mengolah air limbah domestik minimal dari 50 KK. 


\section{Potensi dan Resiko Bencana}

Dalam satu sisi adanya gunung berapi sangat menyuburkan kondisitanah di sekitar Yogyakarta, tetapi disisi lain juga sangat riskan adanya bencana letusan gunung berapi. Potensi terjadinya banjir ada di wilayah Kelurahan Klitren, terutama pada permukiman di sepanjang sungai Belik. Dengan demikian diperlukan penyeleggaraan penanggulangan bencana secara terpadu. Termasuk pula dengan lingkungan yang tidak teratur serta padat menyebabkan resiko kebakaran juga tinggi. Persyaratan kran kebakaran berdasarkan RDTR Kota Yogyakarta (2015)

- Kran kebakaran diletakkan pada jarak 100 m dari bangunan komersial

- Kran kebakaran diletakkan 200 m dari perumahan

- Diletakkan pada tempat yang dapat dijangkau unit kebakaran

\section{DiskUSI Kolaborasi PEMBANGUNAN KAMPUNG KOTA}

Ada banyak strategi yang diimplementasikan untuk membangun kampung kota, baik oleh pemerintah maupun oleh pihak LSM dan institusi lainnya. [5] Pada umumnya di beberapa negara berkembang di Afrika, Latin Amerika dan Asia melakukan proses pengembangan kampung kumuh (Slum Area dan Squatter Setlement) dilakukan secara partisipatoris dengan melibatkan masyarakat yang menjadi target group. [6] Salah satu strategi yang cukup baik adalah melakukan proses pengembangan secara kolaborasi, naik dari pemerintah daerah, LSM dan Akademisi dari Institusi Perguruan Tinggi. [7]

Peranan akademisi dalam kolaborasi membangun Kampung kota adalah melakukan trasfer of knowledge dari teori-teori yang dipelajari secara akademik dalam bidang Arsitektur, Permukiman dan Perkotaan kepada semua pemangku kepentingan (stakeholder) terutama masyarakat yang tinggal di kampung kota. Dengan demikian wilayah kampung kota yang menjadi target area dan masyarakatnya yang menjadi target group akan menjadi laboratorium hidup untuk mempraktekkan dan mengembangkan teori yang selama ini dipelajari di kampus. [8]

Kolaborasi dapat diartikan sebagai suatu hubungan jangka panjang yang dilandasi oleh saling pengakuan dan pengertian antara pihak-pihak yang terlibat sehingga keberhasilan yang dicapai tidak dapat diclaim sebagai keberhasilan satu pihak saja. Interaksi antar pemangku kepentingan berdasarkan atribut kemitraan, yaitu saling ketergantungan, kepercayaan, dan komitmen. [9] Dalam membangun kampong kota yang menjadi fokus pembangunan adalah masyarakat beserta lingkungan permukiman tempat tinggal mereka. Dengan kata lain, semua pemangku kepentingan akan berkolaborasi untuk membuat perencanaan dengan mengajak masyarakat secara partisipatif untuk memikirkan perencanaan kampung kota. Interaksi berdasarkan kemitraan, kepercayaan dan komitmen bersama dengan masyarakat menjadi ikatan yang kuat dalam merencanakan pembangunan wilayah kampung kota berikut dengan implementasinya.

Dalam membuat perencanaan kolaborasi masing-masing pemangku kepentingan akan berperan sesuai dengan kapabilitas masing-masing. Sebagai akademisi peranan yang diberikan lebih banyak pada proses pemberdayaan masyarakat melalui Focus Group Disussion dan workshop yang dilakukan secara berseri. Sementara pihak pemeirntah akan mengkoreksi hasil desain yang dibuat dan membiayai kebutuhan dana untuk mengimplementasikan perencanaan yang sudah dibuat. [10] Pihak pemerintah daerah dapat membiayai program, karena pemerintah mempunyai dana yang sudah dianggarkan dalam periode satu tahun berjalan. Kolaborasi yang baik akan memungkinkan tercapainya tujuan bersama sesuai dengan apa yang diprediksikan sebelumnya. Karena dalam proses kolaborasi memerlukan kerjasama dalam pemikiran atau perencanaan program, pelaksanaan sampai dengan evaluasi capaian program. [11]

Kolaborasi juga membutuhkan waktu dan jika hubungan di antara para pihak tidak terlalu penting maka kemungkinan hasil yang didapatkan tidak sepadan dengan waktu dan energi untuk menciptakan solusi bersama (winwin solution). [12] Oleh sebab itu dalam melakukan kolaborasi perencanaan kampung kota semua pemangku kepentingan harus bersama dengan komitmennya melakukan perencanaan pembangunan kampung kota bersama masyarakat setempat. Disisi lain pihak masyarakat kampung kota yang permukimannya direncnakan untuk dikembangkan harus membuka diri dan mau belajar untuk nantinya berkembang secara mandiri.

Rencana pengembangan kampung kota akan menjadi sefektif dan efisien apabila komunikasi antar pemangku kepentingan dapat terjalin dengan baik dan tidak ada satupun dari pemangku kepentingan mengambil keuntungan materi dalam melakukan perencanaan kolaborasi. [13] Keharmonisan dalam melakukan kolaborasi dapat tercermin dalam akuntabilitas dan keterbukaan mengelola dana yang disediakan untuk proses perencanaan dan implementasinya.

\section{Metode PELAKSANAAN PENDAMPINGAN}

Metode pendampingan yang dilakukan pada masyarakat kampung kota di wilayah Kelurahan Klitren dilakukan secara kolaboratif oleh tim Laboratorium Lingkungan Kota dan Permukiman (LLKP), FAD - UKDW, tim Korkot Program KOTAKU dan Dinas PU PKP Kota Yogyakarta. Proses pendampingan yang dilakukan di konsentrasikan pada pemberdayaan masyarakat melalui pembangunan fasilitas infrastruktur kampung kota untuk memperbaiki kwalitas lingkungan permukiman. 
Langkah awal yang dilakukan adalah melakukan koordinasi untuk membagi peran dalam proses pendampingan pada masyarakat kampung di wilayah Kelurahan Klitren. Pada koordinasi tersebut disepakati dengan membuat komitmen bahwa semua pemangku kepentingan harus dengan tulus hati memberikan kontribusinya pada perencanaan pembangunan. Langkah berikutnya komitmen yang ada diterjemahkan ke dalam pembagian peran masing-masing pemangku kepentingan dalam proses perencanaan dan implementasinya.

Proses ini masih relevan untuk diterapkan dalam proses pemberdayaan masyarakat yang mengintensifkan kolaborasi pemangku kepentingan dalam membangun permukiman kampung kota. Pemangku kepentingan seperti Akademisi, dinas pemerintah daerah, LSM, Masyarakat, dll membentuk tim yang akan melaksanakan perencanaan partisipatif berbasis masyarakat [14] Sebagai akademisi tim LLKP, FAD - UKDW mempunyai peran dalam proses memberdayakan masyarakat melalui proses perencanaan partisipatif berbasis masyarakat. Proses pemberdayaan ini diawali dengan memotret lingkungan permukiman kampung kota di wilayah Kelurahan Klitren. Setelah itu dilakukan FGD untuk mendiskusikan permasalahan dan potensi yang ditemukan di lapangan. Setelah itu dilakukan serial workshop beberapa kali bersama masyarakat, PU PKP dan tim KOTAKU sampai menemukan pemecahan masalah dan strategi meningkatkan potensi yang ada. Pada akhirnya disusunlah perencanaan pembangunan kampung kota di wilayah Kelurahan Klitren.
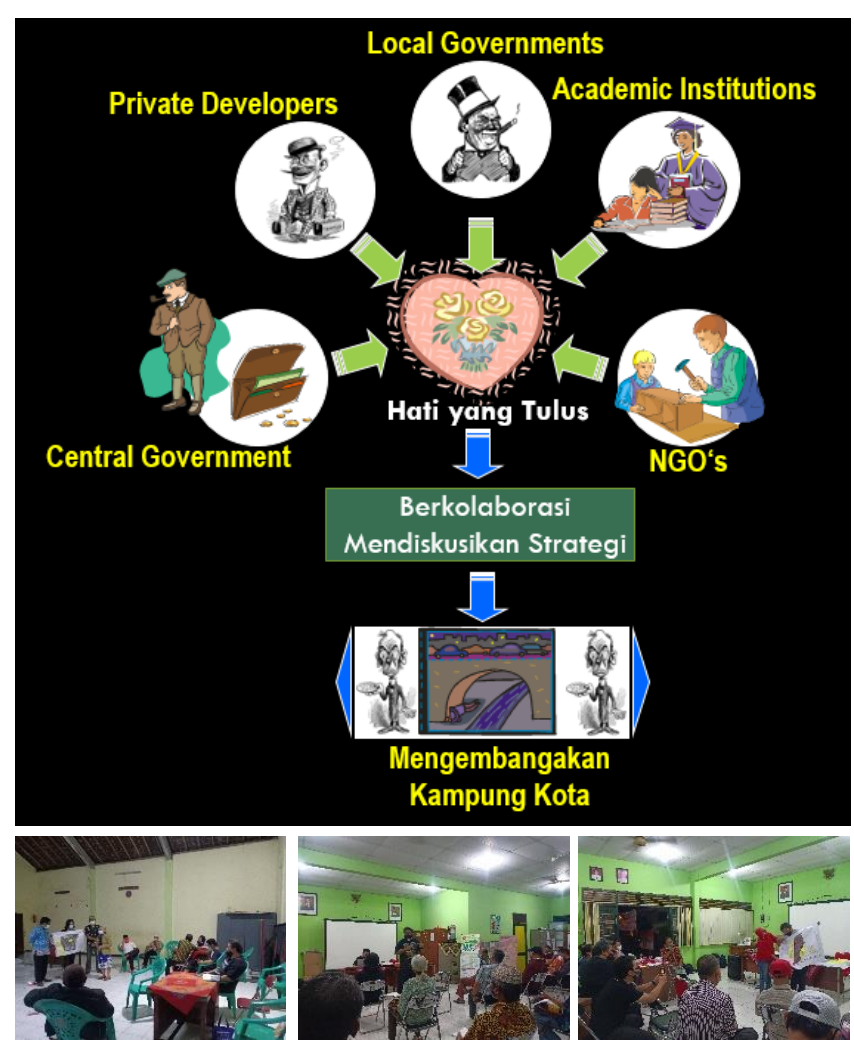

Gambar 3. Metode Kolaborasi Pelaksanaan Pengembangan Kampung Kota

Sumber: Dokumentasi Pribadi

Setelah perencanaan kampung kota selesai dibuat pihak Dinas PU PKP membuat gambar-gambar detail yang dibantu oleh tim KOTAKU dan tim LLKP, FAD-UKDW. Dalam pelaksanakan pembangunan di kampung kota Kelurahan Klitren berperan melalui Badan Keswadayaan Masyarakat dan Lembaga Pemberdayaan Masyarakat Kelurahan. Kedua lembaga ini menjadi tulang punggung Kelurahan Klitren dalam melaksanakan pembangunan dan mengkoordinasikan masyarakat setempat untuk berpartisipasi dalam semua proses yang sudah dilakukan.

\section{KeKUAtan Kolaborasi Dalam MEMBANGUN KAMPUNG PERKOTAAN}

Proses perencanaan pembangunan wilayah Kelurahan Klitren yang sudah dilakukan secara kolaboratif merupakan pembelajaran yang dapat menguatkan masing-masing pemangku kepentingan. Masyarakat sebagai target group yang diberdayakan kapabilitasnya mempunyai keberanian untuk memberikan usulan-ulusan yang bermanfaat untuk peningkatan infrastruktur, perbaikan permukiman dan pengembangan fasilitas - fasilitas yang dapat mendukung perkembangan ekonomi masyarakat berpenghasilan rendah. Walaupun masyarakat setempat tidak pernah belajar tentang Arsitektur, Ekonomi dan ilmu-ilmu yang relevan untuk 
pembangunan kawasan, namun mereka sanggup berfikir dan memberikan usulan-usulan teknis yang sangat relevan dengan kebutuhan mereka sehari-hari. [15] Mereka sanggup memberikan usulan-usulan pengembangan karena mereka memang hidup dan tinggal di kampung-kampung kota Kelurahan Klitren dalam waktu yang cukup lama.

Sebelum pembuatan rencana pengembangan kampunng kota di wilayah Kelurahan Klitren dibuat, sebenarnya proses kolabirasi juga sudah dilakukan untuk membangun beberapa bagian wilayah kampung kota dalam program KOTAKU. Pihak pemerintah sebagai pihak yang memberikan kebijakan tentang pembangunan dan mengimplementasikan perencanaan yang sudah dibuat juga dapat memahami kearifan lokal masyarkat dalam membangun kampung kota. Selain itu berkolaborasi dengan akademisi bersama masyarakat akan memperkaya altrenatif pemecahan masalah dan meningkatkan potensi yang ada pada permukiman kampung kota. Tahapan pelaksanaan pembangunan akan dapat disepakti bersama, apabila komunikasi dengan semua pemangku kepentingan bisa berjalan dengan baik.

Pembangunan yang sudah dilaksanakan di wilayah Kelurahan Klitren dilaksanakan pada beberapa wilayah kampung kota seperti perbaikan infrastruktur jalan, drainage, air bersih dan pengolahan limbah komunal. Proses pembangunan jalan inspeksi di sisi kiri dan kanan sungai Belik saat ini masih dalam proses pembangunan. Untuk membangun jalan inspeksi ini banyak rumah yang harus dimundurkan dindingnya antara satu sampai dengan satu setengah meter. Kerelaan masyarakat untuk memundurkan dinding rumahnya merupakan bentuk kontribusi luar biasa dari masyarakat setempat untuk meningkatkan kwalitas lingkungan permukiman mereka. Semua proses yang dilakukan dalam membangun kampung kota di wilayah Klitren merupakan hasil kolaborasi dari semua pihak yang mendukung pmbangunan kampung kota di wilayah Kelurahan Klitren.

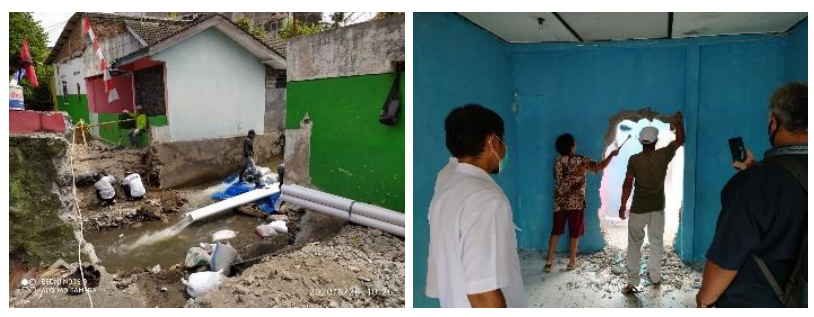

Gambar 4. Pembongkaran rumah di tepi sungai Belik untuk membangun jalan inspeksi.

Sumber: Dokumentasi Pribadi

Selain membangun jalan inspeksi di sepanjang tepi sungai Belik, beberapa bagian jalan di tengah kampung juga diperbaiki dengan membuat jalan paving. Proses pemberdayaan atau transfer of knowledge pada masyarakat melalui pembangunan fasilitas infrastruktur kampung kota dapat membuahkan hasil yang baik apabila dilaksanakan secara baik tahapannya. [16] Diharapkan pembangunan jalan yang sudah dibuat oleh pemerintah daerah yang berkolaborasi dengan akademisi dapat dipelihara dengan baik oleh masyarakat setempat.

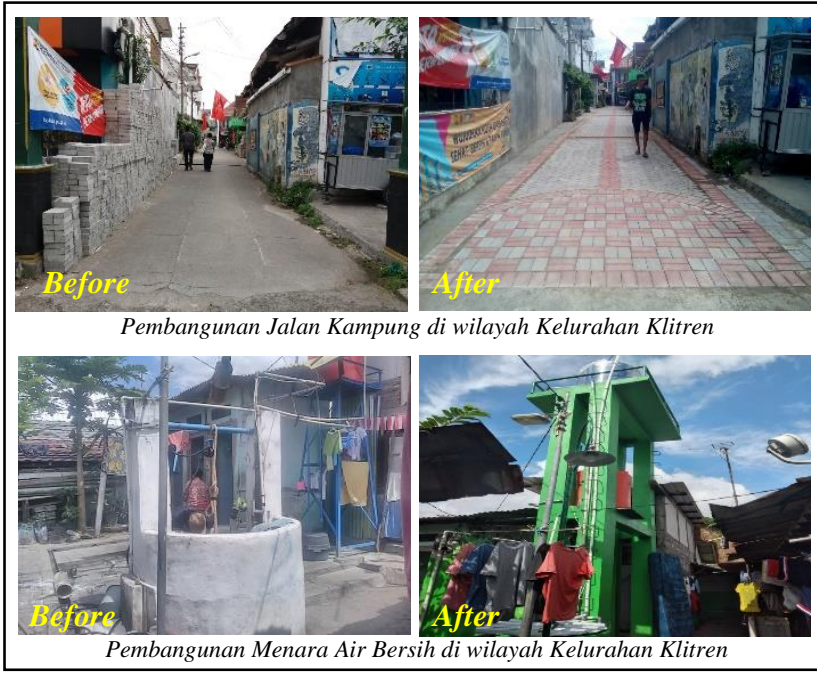

Gambar 3. Metode Kolaborasi Pelaksanaan Pengembangan Kampung Kota

Sumber: Dokumentasi Program KOTAKU - RPLP Klitren

Tim Laboratorium Lingkungan Kota dan Permukiman, FAD - UKDW sebagai akademisi mendapatkan banyak pembelajaran dalam melakukan kolaborasi dengan pihak pemerintah daerah dan masyarakat. Menjadikan wilayah Kelurahan Klitren sebagai laboratorium hidup untuk bidang Arsitektur, Permukiman dan Perkotaan sangat membantu proses belajar mengajar bagi mahasiswa yang terlibat dalam kegiatan pembangunan wilayah Kampung Klitren. Selain itu setiap dosen yang terlibat dalam proses perencanaan partisipatif bersama masyarakat semakin menambah wawasan tentang bagaimana memahami masyarakat dalam mengekspresikan kebutuhan mereka untuk meningkatkan kehidupan dan penghidupan serta kwalitas lingkungan tempat tinggal mereka.

Sesuai dengan pendapat Agustiana dan Budiastuti bahwa kolaborasi dapat diartikan sebagai suatu hubungan jangka panjang yang dilandasi oleh saling pengakuan dan pengertian antara pihak-pihak yang terlibat dan interaksi antar pihak tersebut didasarkan pada atribut kemitraan, yaitu kepercayaan, dan komitmen. Pada pembangunan kampung kota di wilayah Kelurahan Klitren, Yogyakarta dapat teridentifikasi dengan jelas bagaimana kekuatan kolaborasi antar pemangku kepentingan dapat mendukung terlaksananya pembuatan rencana pembangunan kampung kota berikut dengan implementasinya. Kepercayaan masyarakat dan komitmen bersama antar pemangku kepentingan sangat mendukung proses pemberdayaan masyarakat dan peningkatan kwalitas lingkungan permukiman dimana mereka tinggal. 


\section{KESIMPULAN DAN SARAN}

Berdasarkan hasil diksusi pada beberapa bab sebelumnya dapat ditarik beberapa kesimpulan yang diformulasikan seperti berikut :

Perencanaan pembangunan wilayah Kelurahan yang dilakukan secara kolabotif merupakan proses pembelajaran yang dapat menguatkan masing-masing pemangku kepentingan.

- Perencanaan kolaborasi berbasis masyarakat dapat mengembangkan fasilitas infrastruktur yang benarbenar dibutuhkan oleh masyarakat seperti jalan kampung, drainage, tandon air bersih, pengolahan limbah komunal.

> Dengan perencanaan kolaboirasi ada proses kerja sama mutualisme antara akademisi dari institusi perguruan dengan pihak kelurahan. Akademisi mepunyai lokasi dampingan yang mejadi laboratorium untuk praktek perencanaan dan perancangan permukiman baik oleh dosen maupun mahasiswa, sementara pihak Kelurahan mempunyai tenaga pemikir akademisi dari perguruan tinggi untuk membangun masyarakat dan lingkungan permukimannnya.

Proses pemeliharaan fasilitas inrfastruktur dan permukiman yng sudah dibangun dapat dipelihara secaa berkelanjutan dengan adanya kerja sama kolaborasi antara phak Kelurahan dengan pihak akademisi dari perguruan tinggi.

\section{DAFTAR PUSTAKA}

[1] P. Bawole, "Community Empowerment Strategy by Sustainable Built Environment Planning in Urban Kampong," in Friendly City 4 "From Research to Implementation for Better Sustainability", Medan, 2018.

[2] S. Panuluh and M. R. Fitri, "Perkembangan Pelaksanaan Sustainable Development Goals (SDGs) di Indonesia," International NGO Forum on Indonesian development, Jakarta, 2016.

[3] B. K. Yogyakarta, "Kota Yogyakarta Dalam Angka 2021," BPS Kota Yogyakarta, Yogyakarta, 2021.

[4] T.-K. Yogyakarta, "Rencana penataan Lingkungan Permukiman Kelurahan Klitren 2017," Unpublihsed Report, Yogyakarta, 2017.

[5] P. Hall, Cities of tomorrow: an intellectual history of urban planning and design since 1880, West Sussex, UK: John Wiley \& Sons Ltd. 2014

[6] D. Mitlin and D. Satterthwaite, Empowring Squatter Citizen : Local Government, Civil Society and Urban Poverty Reduction, London, UK: Earthscan, 2004

[7] W. Indrajit and Soimin, Pemberdayaan Masyarakiat dan Pembangunan, Malang: Intrans Publishing, 2014.

[8] Y. D. Searcy, "Planning Office and Community Influence on LandUse Decisions Intended to Benefit the Low-Income: Welcome to Chicago," in URBAN LAND USE: Community-Based Planning, Oakville, Canada, Apple Academic Press Inc., 2017, pp. 143-162.

[9] F. Agustiana and D. Budiastuti, "The Influence of Dynamic Capability and Collaboration Strategy on the Company Positional
Advantage," International Journal of Advanced Science and Technology, vol. 29, no. 6, pp. 1226-1234, 2020.

[10] I. Kustiawan and A. Ramadhan, "Strategi Peningkatan Kualitas Lingkungan Kampung-Kota dalam Rangka Pembangunan Kota yang Inklusif dan Berkelanjutan: Pembelajaran dari Kasus Kota Bandung," Journal of Regional and Rural Development Planning, vol. 3, no. 1, pp. 64 - 84, 2019.

[11] A. Larantika, S. Zauhar, M. Makmur and E. Setyowati, "Collaboration as a Strategy for Poverty evualation," International Journal of Social Sciences and Humanities, vol. 1, no. 3, pp. 40-48, 2017.

[12] E. Munindi, J. Mwarnia and J. Metet, "The Influence of Collaboration as a Conlict Management Style on Academic Performance in Secondary Schools in Makueni Sub-County, Makueni County, Kenya," International Journal of Education and Research, vol. 5, no. 2, pp. 49-60, 2017.

[13] C. Obermayr, Sustainable City Management, Cham, Switzerland: Springer International Publishing AG., 2017.

[14] P. Bawole, "Empowering the Poor in Urban Kampung Settlements by Intensifying Stakeholder Collaboration in Creating Develoopment Plan," in The 4. Binnale International Conference on Indonesian Architecture and Planning, Yogyakarta, 2018.

[15] S. S. Coughlin, S. A. Smith and M. E. Fernandez, Handbook of Community-Based Participatory Research, New York, USA: Oxford University Press, 2016.

[16] H. Hikmat, Strategi Pemberdayaan Masyarakat, Bandung: Humaniora, 2013. 